\title{
Savoronala, a new genus of Malmideaceae (Lecanorales) from Madagascar with stipes producing sporodochia
}

\author{
Damien Ertz • Eberhard Fischer • Dorothee Killmann • \\ Tahina Razafindrahaja $\cdot$ Emmanuël Sérusiaux
}

Received: 16 August 2012 /Revised: 30 October 2012 /Accepted: 2 November 2012 /Published online: 12 December 2012

(C) German Mycological Society and Springer-Verlag Berlin Heidelberg 2012

\begin{abstract}
The new genus and species Savoronala madagascariensis is a lichenized hyphomycete characterized by its pale glaucous placodioid thallus with erect, short but robust stipes apically producing sporodochia with brown, subspherical conidia, whose cells are wrapped around a single chlorococcoid algal cell. Phylogenetic analyses using nuLSU and mtSSU sequences place Savoronala in the Malmideaceae (Lecanorales). The new species was collected on Erica stems and inhabits coastal dunes near Taolanaro (southeast Madagascar). Lecidea floridensis is shown to belong to Malmidea whereas Lecidea cyrtidia and L. plebeja are also resolved in the Malmideaceae. The genus Sporodochiolichen Aptroot \& Sipman is reduced into synonymy with Tylophoron.
\end{abstract}

Keywords Anamorphic fungi - Lecanoromycetes · Sporodochiolichen $\cdot$ Madagascar $\cdot$ Phylogeny

D. Ertz $(\bowtie)$

Department Bryophytes-Thallophytes,

National Botanic Garden of Belgium, Domaine de Bouchout,

1860 Meise, Belgium

e-mail: damien.ertz@br.fgov.be

E. Fischer $\cdot$ D. Killmann

Department of Biology, Institute for Integrated Natural Sciences,

University of Koblenz-Landau, Universitätstraße 1,

56070 Koblenz, Germany

T. Razafindrahaja

Département Botanique, Parc de Tsimbazaza, B.P. 4096,

Antananarivo 101, Madagascar

E. Sérusiaux

Evolution and Conservation Biology, University of Liège,

Sart Tilman B22,

4000 Liège, Belgium

\section{Introduction}

Madagascar is one of the world's most important biodiversity hotspots (Myers et al. 2000). The island harbors a very rich and diverse angiosperm flora with an estimation of $\mathrm{c}$. 12,000 species (Schatz et al. 1996), with c. $80 \%$ considered to be endemic. Indeed, all segments of the biodiversity of the island are very rich in species, most of them being endemic (Goodman and Beanstead 2003). The rate of discovery of new taxa is unabated, including in supposedly well-known groups such as the lemurs (discovery of a further new species of Microcebus in 2012: Radespiel et al. 2012), or the chameleons (a puzzling number of cryptic species has just been demonstrated in the dwarf genus Brookesia: Glaw et al. 2012).

This contrasts sharply with the lichen flora as a mere 157 species are included in the only available check-list (Aptroot 2012); an unpublished list by the same author has 368 accessions. During a field trip in 2008, we could prospect several biomes, e.g. montane rainforests, rock outcrops and coastal sand dunes, and could make numerous new records for the island. New species were discovered such as Syncesia madagascariensis (Ertz et al. 2010) that was eventually found in La Réunion (van den Boom et al. 2011). Most of the new records, however, comprise widespread species not confined to Madagascar. Endemism is thus most probably much lower than in vascular plants. As an example, the dry spiny forests around the city of Toliara are a hotspot for endemic angiosperms while the lichen flora is rather species-poor. Important areas for lichen diversity seem to be situated in the montane rainforests where urgent conservation measures are needed. Another area that proved to be very rich in lichens are the coastal sands near the city of Taolanaro (southeast Madagascar) where we collected a very puzzling lichenized hyphomycete with stipes producing 
sporodochia that represents a new species for science, being considered a genus of its own. The aim of the present paper is to describe it and to determine its phylogenetic position.

\section{Material and methods}

Hand-made sections were investigated light-microscopically in water and $5 \% \mathrm{KOH}$. Microscopical measurements all refer to material examined in $5 \% \mathrm{KOH}$, which dissolves surrounding crystals. Chemical reactions were tested using $\mathrm{KOH}(\mathrm{K})$ and Lugol's reagent without (I) or with $(\mathrm{K} / \mathrm{I})$ pretreatment with K. Thin-layer chromatography (TLC) of acetone extracts was performed in solvent systems B and G (Orange et al. 2001). Air-dried herbarium material for study by SEM was mounted on polished aluminium stubs using a transparent two-component epoxy glue, gold-coated in a Balzers Union SCD 040 sputter and examined in a Cambridge Stereoscan S 200 scanning electron microscope.

Two well-preserved specimens of the new taxon lacking any visible symptoms of fungal infection were sampled for DNA isolation. Extraction of DNA and PCR amplification were performed following the protocol of Cubero et al. (1999). The following primers were used: for mtSSU: mrSSU1 and mrSSU3R (Zoller et al. 1999); for nuLSU: LIC2044, LR0R, LR3R, LR3, and LR6 (Kauff and Lutzoni 2002; Rehner and Samuels 1994; Vilgalys and Hester 1990). Amplicons were sequenced by Macrogen ${ }^{\circledR}$. Sequence fragments were assembled with Sequencher v.4.9 (Gene Codes, Ann Arbor, MI, USA). Sequences were subjected to MEGABLAST searches to detect potential contamination.

We first built a matrix of LSU sequences retrieved from GenBank and representing all major clades of the Ascomycota following Schoch et al. (2009), to assess that our material actually belongs to the Lecanoromycetes as expected. The sampling covered the whole phylogenetical variation of the Ascomycota, including representatives of Taphrinomycetes, Saccharomycetes, Pezizomycetes, Orbiliomycetes, Arthoniomycetes, Dothideomycetes, Eurotiomycetes, Lecanoromycetes, Lichinomycetes, Leotiomycetes, and Sordariomycetes. A single maximum likelihood (ML) analysis was performed with GARLI (v.0.951 for OSX; Zwickl 2006) and the branches of the single most likely tree produced were evaluated with 100 pseudoreplicates (data not shown). As our material was resolved within the Lecanoromycetes, albeit with weak support, we could proceed with phylogenetical analyses focusing on that clade.

A selection of taxa having both nuLSU and mtSSU sequences were chosen from the studies of Schmull et al. (2011) and Kalb et al. (2011) to generate a phylogenetic tree including the main groups of the Lecanoromycetidae. The taxa listed in Table 1 were aligned manually using MacClade 4.05 (Maddison and Maddison 2002). The outgroup species
Table 1 DNA sequences used in this study; GenBank accession numbers in bold (4) refer to sequences generated by this project, all other sequences (148) were obtained directly from GenBank

\begin{tabular}{|c|c|c|}
\hline Taxa & nuLSU & mtSSU \\
\hline Bacidia rosella (Pers.) De Not. & 37960788 & 32141050 \\
\hline $\begin{array}{l}\text { Bacidina arnoldiana (Körb.) V. Wirth \& } \\
\text { Vězda }\end{array}$ & 119514008 & 119514020 \\
\hline $\begin{array}{l}\text { Bryoria trichodes (Michx.) Brodo \& D. } \\
\text { Hawksw. }\end{array}$ & 119513961 & 119514140 \\
\hline Buellia punctata (Hoffm.) A. Massal. & 119513966 & 119514131 \\
\hline Byssoloma leucoblepharum (Nyl.) Vain. & 59323706 & 50082856 \\
\hline Calopadia foliicola (Fée) Vězda & 59323707 & 50082860 \\
\hline Catolechia wahlenbergii (Ach.) Flot. & 119514004 & 119514021 \\
\hline Cladia retipora (Labill.) Nyl. & 34148718 & 34148561 \\
\hline $\begin{array}{l}\text { Cladonia rangiferina (L.) Weber ex F.H. } \\
\text { Wigg. }\end{array}$ & 46852258 & 32141054 \\
\hline Crocynia pyxinoides $\mathrm{Nyl}$ & 46411442 & 46411380 \\
\hline $\begin{array}{l}\text { Degelia plumbea (Lightf.) P.M. Jørg. \& P. } \\
\text { James }\end{array}$ & 119643345 & 119642269 \\
\hline Evernia prunastri (L.) Ach. & 6318536 & 15987426 \\
\hline Fellhanera bouteillei (Desm.) Vězda & 59323777 & 50082865 \\
\hline $\begin{array}{l}\text { Fellhanera subtilis (Vězda) Diederich \& } \\
\text { Sérus. }\end{array}$ & 59323710 & 50082864 \\
\hline Frutidella caesioatra (Schaer.) Kalb & 59323778 & 50082843 \\
\hline Hypogymnia physodes (L.) Nyl. & 123979301 & 123979249 \\
\hline Hypotrachyna caraccensis (Taylor) Hale & 119643035 & 119641533 \\
\hline Imshaugia aleurites (Ach.) S.L.F. Mey. & 119513963 & 119514121 \\
\hline Japewia tornoensis (Nyl.) Tønsberg & 113473520 & HQ660559 \\
\hline Lecania cyrtella (Ach.) Th. Fr. & 37960799 & 32141064 \\
\hline Lecanora achariana A.L. Sm. & 123979298 & 123979247 \\
\hline Lecanora contractula $\mathrm{Nyl}$. & 119513956 & 119514155 \\
\hline Lecanora fuscescens (Sommerf.) Nyl. & HQ660532 & HQ660555 \\
\hline Lecanora hybocarpa (Tuck.) Brodo & 110666897 & 119641323 \\
\hline Lecanora intumescens (Rebent.) Rabenh. & 37960800 & 32141065 \\
\hline Lecanora muralis (Schreb.) Rabenh. & HQ660533 & HQ660556 \\
\hline Lecanora polytropa (Ehrh.) Rabenh. & 119514002 & 119514017 \\
\hline Lecidea berengeriana (A. Massal.) Nyl. & HQ660537 & HQ660562 \\
\hline Lecidea cyrtidia Tuck. & HQ660538 & HQ660563 \\
\hline Lecidea floridensis $\mathrm{Nyl}$. & HQ660540 & HQ660565 \\
\hline Lecidea fuscoatra (L.) Ach. & 119642943 & 119641368 \\
\hline Lecidea nylanderi (Anzi) Th. Fr. & HQ660545 & HQ660572 \\
\hline Lecidea plebeja $\mathrm{Nyl}$. & HQ660549 & HQ660577 \\
\hline Lecidea pullata (Norman) Th. Fr. & HQ660546 & HQ660574 \\
\hline Lecidea roseotincta Coppins \& Tønsberg & HQ660547 & HQ660575 \\
\hline Lecidea turgidula Fr. & 59323712 & 50082866 \\
\hline $\begin{array}{l}\text { Lecidella meiococca (Nyl.) Leuckert \& } \\
\text { Hertel }\end{array}$ & 37960801 & 32141066 \\
\hline Lepraria incana (L.) Ach. & 119514005 & 119514022 \\
\hline Lobaria scrobiculata (Scop.) P. Gaertn. & 46411444 & 46411386 \\
\hline Malmidea coralliformis Kalb & HM447627 & HM447597 \\
\hline Malmidea ееииае Kalb & HM447628 & HM447601 \\
\hline Masonhalea richardsonii (Hook.) Kärnefelt & 123979302 & 123979250 \\
\hline Megalaria grossa (Pers. ex Nyl.) Hafellner & 59323785 & 58891484 \\
\hline Megalospora tuberculosa (Fée) Sipman & 46411439 & 46411388 \\
\hline
\end{tabular}


Table 1 (continued)

\begin{tabular}{|c|c|c|}
\hline Таха & nuLSU & $\mathrm{mtSSU}$ \\
\hline Micarea adnata Coppins & 59323715 & 50082829 \\
\hline Micarea alabastrites (Nyl.) Coppins & 59323716 & 50082842 \\
\hline $\begin{array}{l}\text { Micarea doliiformis (Coppins \& P. James) } \\
\text { Coppins \& Sérus. }\end{array}$ & HQ660534 & HQ660557 \\
\hline $\begin{array}{l}\text { Micarea (Leimonis) erratica (Körb.) Hertel, } \\
\text { Rambold \& Pietschm. }\end{array}$ & 59323717 & 50082815 \\
\hline $\begin{array}{l}\text { Micarea micrococca (Körb.) Gams ex } \\
\text { Coppins }\end{array}$ & 59323719 & 50082827 \\
\hline Micarea sylvicola (Flot.) Vězda \& V. Wirth & 5932 & 50082847 \\
\hline Mycoblastus sanguinarius (L.) Norman & 119642962 & 119641393 \\
\hline Neophyllis melacarpa F. Wilson & 34148734 & 34148585 \\
\hline Niebla cephalota (Tuck.) Rundel \& Bowler & 119513972 & 119514150 \\
\hline $\begin{array}{l}\text { Parmotrema reticulatum (Taylor) M. } \\
\text { Choisy }\end{array}$ & 119643103 & 119641619 \\
\hline Peltigera degenii Gyeln. & & 46411393 \\
\hline Phaeophyscia orbicularis (Neck.) Moberg & 119643263 & 119641752 \\
\hline Placynthium nigrum (Huds.) Gray & 15216685 & 46411472 \\
\hline $\begin{array}{l}\text { Porpidia albocaerulescens (Wulfen) Hertel } \\
\text { \& Knoph }\end{array}$ & 119513967 & 119514128 \\
\hline Protoblastenia calva (Dicks.) Zahlbr. & 4685 & 119514161 \\
\hline $\begin{array}{l}\text { lria pezizoides (Weber) P.M. } \\
\text { Ekman }\end{array}$ & 119643399 & 119642318 \\
\hline Pseudevernia furfuracea (L.) Zopf & 5095 & 15987445 \\
\hline Psilolechia leprosa Coppins \& Purvis & 59323722 & 50082808 \\
\hline Psilolechia lucida (Ach.) M. Choisy & 59323723 & 50082807 \\
\hline Psora decipiens (Hedw.) Hoffm. & 119513970 & 119514120 \\
\hline Pyrrhospora quernea (Dicks.) Körb. & 37960817 & 32141081 \\
\hline Ramalina complanata (Sw.) Ach. & 113707378 & 123979257 \\
\hline Rhizocarpon geographicum (L.) DC. & 62005347 & 29837334 \\
\hline Savoronala madagascariensis 537 & КС020142 & КC020144 \\
\hline Savoronala madagascariensis 538 & КС020143 & КC020145 \\
\hline Scoliciosporum umbrinum (Ach.) Arnold & 52699715 & 32141084 \\
\hline Solorina saccata (L.) Ach. & 123979315 & 123979265 \\
\hline Sphaerophorus globosus (Huds.) Vain. & 119513977 & 119514123 \\
\hline Sporastatia testudinea (Ach.) A. Massal. & 52699717 & 46411480 \\
\hline Stereocaulon tomentosum Th. Fr. & 34148745 & 34148600 \\
\hline Tephromela atra (Huds.) Hafellner & 119513974 & 119514151 \\
\hline Xanthoria elegans (Link) Th. Fr. & 119643441 & 11964238 \\
\hline
\end{tabular}

Sporastatia testudinea was chosen based on Schmull et al. (2011). Ambiguous regions and introns representing a total of $2,867 \mathrm{bp}$ were delimited on the alignment of Schmull et al. (2011) retrieved from the AFTOL website and excluded from the analyses after realigning the portions that were ambiguous in the larger dataset.

Analyses for topological incongruence among loci were carried out using 1,000 replicates of neighbor-joining bootstrapping (NJ-bs) with distance measure estimated by maximum likelihood under a six-parameter (GTR) best-fit evolutionary model for nucleotide substitution (Cunningham et al. 1998; Liò and Goldman 1998; Yang et al. 1994) using
PAUP* 4.0b10 (Swofford 2002). Best-fit evolutionary models were estimated for all $\mathrm{NJ}$ analyses using Akaike Information Criterion (AIC) as implemented in Modeltest v.3.06 (Posada and Crandall 1998). The GTR $+\mathrm{I}+\mathrm{G}$ model was selected for the nuLSU and the mtSSU datasets. All topological bipartitions with NJ-bs values $\geq 70 \%$ were compared for the two loci. A conflict was assumed to be significant if two different relationships (one being monophyletic and the other being non-monophyletic) for the same set of taxa were both supported with bootstrap values $\geq 70 \%$ (Mason-Gamer and Kellogg 1996). Based on this criterion, no conflict was detected and therefore the nuLSU and mtSSU datasets were concatenated. The combined twoloci dataset consisted of 76 taxa and 1,624 unambiguously aligned sites, 1,171 for nuLSU and 453 for mtSSU.

Bayesian analyses were carried out on the two-loci dataset using the Metropolis-coupled Markov chain Monte Carlo method (MCMCMC) in MrBayes v.3.1.2 (Huelsenbeck and Ronquist 2001; Ronquist and Huelsenbeck 2003) on the CIPRES portal (Miller et al. 2010). Analyses were run under the selected model for each gene partition using a gammadistributed rate parameter and a proportion of invariable sites. Two parallel MCMCMC runs were performed each using four independent chains and 20 million generations, sampling trees every 1,000th generation. TRACER v.1.5 (Rambaut and Drummond 2007) was used to ensure that stationarity was reached by plotting the log-likelihood values of the sample points against generation time. Posterior probabilities (PP) were determined by calculating a majority-rule consensus tree generated from the 30,000 post-burnin trees of the 40,000 trees sampled by the two MCMCMC runs using the sumt option of MrBayes. The ML analysis was performed on the two-loci dataset using GARLI (v.0.951 for OSX; Zwickl 2006) with default settings, and a single most likely tree was produced $(-\operatorname{lnL}=130,69.1812)$. One thousand bootstrap pseudoreplicates were used to calculate a majority rule consensus tree in PAUP* to assess the ML bootstrap values (ML-bs). The Bayesian tree did not contradict the ML tree topology for the strongly supported branches and hence only the majority rule consensus tree of the ML analysis is shown here with the branches supported by the Bayesian analysis represented by thicker lines (Fig. 1). ML-bs $\geq 70 \%$ and PP $>90 \%$ were considered to be significant. Phylogenetic trees were visualized using FigTree v.1.3.1 (Rambaut 2012).

A further dataset was assembled with all mtSSU accessions of Malmidea Kalb, Rivas Plata \& Lumbsch in Kalb et al. (2011) together with the same loci accessions of Lecidea cyrtidia and L. floridensis in Schmull et al. (2011) and our sequences of Savoronala. An unweighted maximum parsimony analysis was run under PAUP* (Swofford 2002), using heuristic searches with 1,000 random addition replicates, with tree bisection-reconnection (TBR) branchswapping, steepest descent not in effect and MulTrees 


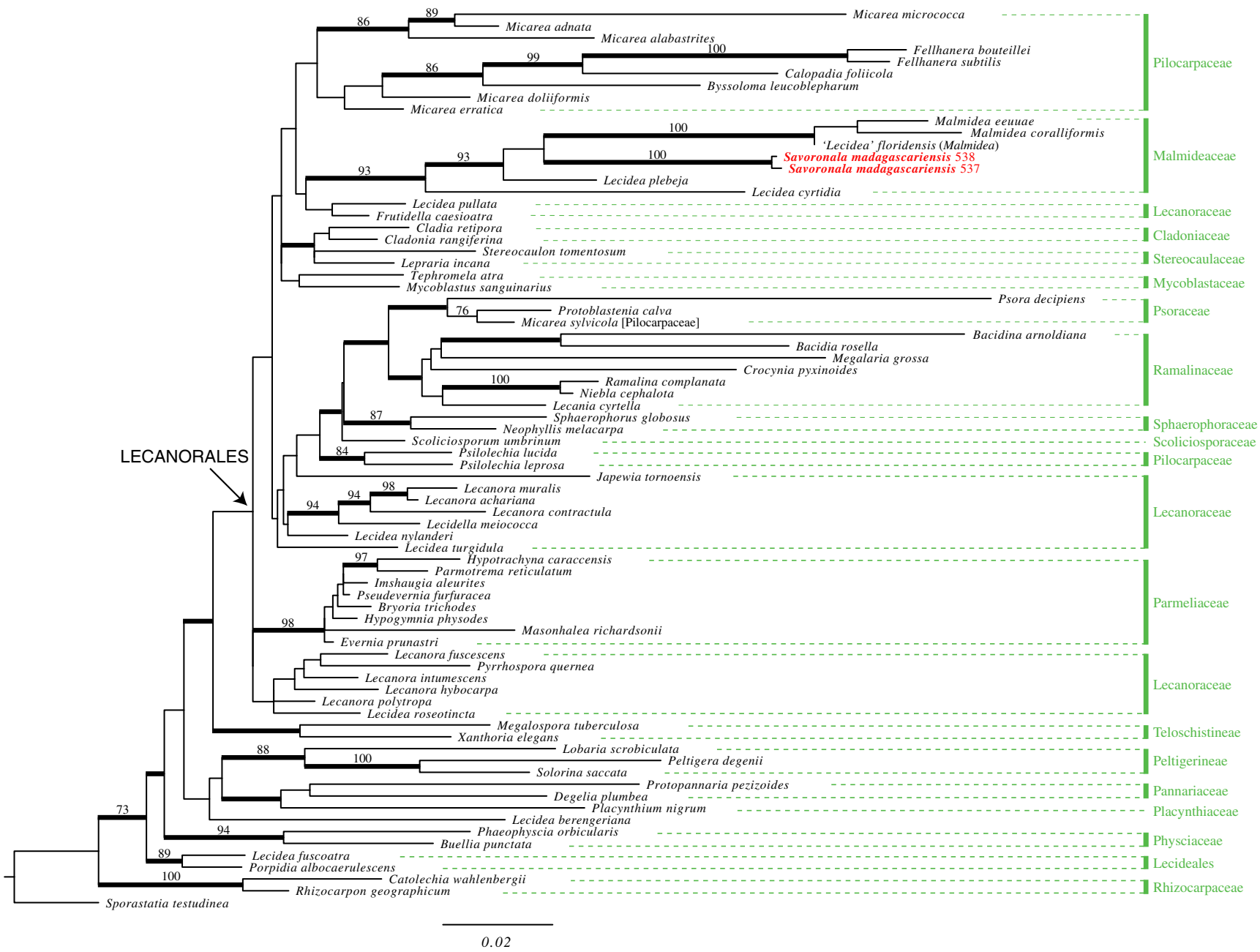

Fig. 1 Phylogenetic relationships among 76 taxa within Lecanoromycetidae based on a combined dataset of nuLSU and mtSSU sequences that resulted from a maximum likelihood analysis. ML-bs values $\geq 70$ are shown above internal branches. Internal branches with a PP $>90 \%$

option in effect. Gaps were treated as missing data. The strength of support for individual branches was estimated using bootstrap values drawn from the $50 \%$ consensus tree constructed from all optimal trees saved during 100 pseudoreplicates heuristic searches.

\section{Results}

Phylogenetic analyses

Our phylogenetic tree is largely congruent with the wellsupported lineages in Schmull et al. (2011) (Fig. 1). Some basal groups are strongly supported by both analyses such as the Rhizocarpaceae (ML-bs=100; PP=100), the Lecideales $(\mathrm{ML}-\mathrm{bs}=89 ; \mathrm{PP}=100)$, the Physciaceae $(\mathrm{ML}-\mathrm{bs}=94 ; \mathrm{PP}=100)$ and t,he Peltigerineae $(\mathrm{ML}-\mathrm{bs}=88 ; \mathrm{PP}=100)$, but the relationships between them are not supported. The Lecanorales resulting from a Bayesian analysis are considered strongly supported and represented by thicker lines. The two specimens of the new genus Savoronala are in red and bold

including most of the terminals are not supported. Families within the Lecanorales are often poorly supported except only for the Parmeliaceae (ML-bs=98; PP=100), the Malmideaceae $(\mathrm{ML}-\mathrm{bs}=93 ; \mathrm{PP}=100)$ and, the Sphaerophoraceae (ML-bs=87; PP=100) the three being well-supported by our analyses. When treated in the sense of Schmull et al. (2011), the Lecanoraceae and Pilocarpaceae are polyphyletic.

The two Savoronala specimens are resolved in a strongly supported clade (ML-bs=100; PP=100) with Lecidea cyrtidia Tuck., L. floridensis Nyl., L. plebeja Nyl. (= L. sp.1 in Schmull et al. 2011), Malmidea coralliformis Kalb and $M$. eeuuae Kalb as part of the Lecanorales. In our phylogenetic tree, the latter clade (named here the Malmideaceae, thus including Lecidea cyrtidia, L. floridensis, L. plebeja, Savoronala, and two species of Malmidea) is sister to two Lecanoraceae, Frutidella caesioatra and Lecidea pullata, but this relationship is not supported. The clade FrutidellaMalmidea is sister to 9 representatives of the Pilocarpaceae 
(5 Micarea, Byssoloma leucoblepharum, Calopadia foliicola and 2 Fellhanera) but this relationship is not supported either. In the six-loci phylogenetic tree by Schmull et al. (2011), the clade Lecidea cyrtidia, L. floridensis and $L$. plebeja ( $=$ L. sp. 1) (without support) together with Micarea doliiformis (Coppins \& P. James) Coppins \& Sérus. (without support) is sister (without support) to the core group of Pilocarpaceae (Byssoloma, Calopadia, Fellhanera and Micarea) and considered as being part of this family. However, the genus Malmidea was missing in the study by Schmull et al. (2011) because sequences of this genus only recently became available (Kalb et al. 2011). The placement of the genus Malmidea in the well-supported group including Lecidea cyrtidia, L. floridensis, L. plebeja and Savoronala led us to consider Savoronala as being part of the Malmideaceae recently described by Kalb et al. (2011).

Finally, the analysis with all $\mathrm{mtSSU}$ accessions of Malmidea, including Lecidea cyrtidia, L. floridensis, and Savoronala, could resolve with strong support Lecidea floridensis within a clade including all accessions of Malmidea (Kalb et al. 2011; tree not shown).

\section{Taxonomy}

Savoronala madagascariensis Ertz, Eb. Fisch., Killmann, Razafin. \& Sérus., gen. et sp. nov. (Figs 2-3)

MycoBank MB 801909 \& MB 801910
Diagnosis: Genus novum ab omnibus generibus ascomycotarum lichenisatarum combinatione signorum sucessivorum differt: thalli parvi placoidei pallide glauci, photobiontes chlorococcoidei, formatio stipium pallide fulvorum cum sporodochia caeruleo-canescentes in apice et conidia fusca cum cellula algarum.

Type: Madagascar, NE Taolanaro (Fort Dauphin), $22 \mathrm{~m}$ alt., $24^{\circ} 56^{\prime} 55.2^{\prime \prime} \mathrm{S}, 47^{\circ} 00^{\prime} 33.2^{\prime \prime} \mathrm{E}$, on base of a stem of Erica, 11 Oct. 2008, D. Ertz 13139, E. Fischer, D. Killmann, V. Razafindrahaja \& E. Sérusiaux (BR-holotypus; TAN, LG, KOBL-isotypi).

Thallus crustose, placodioid, adnate and \pm tightly attached on bark, forming rosettes and with sporodochiaproducing stipes when only reaching $(0.5-) 1 \mathrm{~mm}$ diam., coalescing to form patches up to $3 \mathrm{~cm}$ diam., pale glaucous green, covered with distinct pruina (easily seen when dry), outer lobes closely contiguous, flat to convex, with a smooth to verruculose, matt surface, esorediate, ecorticate; lobe ends not incurved; medulla hyphae irregularly branched, hyaline, mainly $1.5-2 \mu \mathrm{m}$ thick, covered by many hyaline crystals dissolving in K; prothallus absent. Photobiont chlorococcoid, cells green, subsphaerical, (4-)5-7(-9) $\mu \mathrm{m}$ in the thalline lobes, 3-5 $(-6) \mu \mathrm{m}$ at the apex of the stipes. Sporodochia forming at the apex of erected stipes; stipes single (rarely two contiguous), developing at the centre of the thallus, never branched, pale cream (sometimes dark brown when covered by other microorganisms), with a verruculose
Fig. 2 Savoronala madagascariensis (isotype KOBL), SEM photographs. a Thallus and a sporodochium on a stipe. b Thallus margin. c 'Mature' conidia. d One 'mature' conidium, showing the many tiny crystals at its surface. Scale bars (a) $500 \mu \mathrm{m}$, (b) 80 $\mu \mathrm{m}$, (c) $10 \mu \mathrm{m}$, (d) $3 \mu \mathrm{m}$
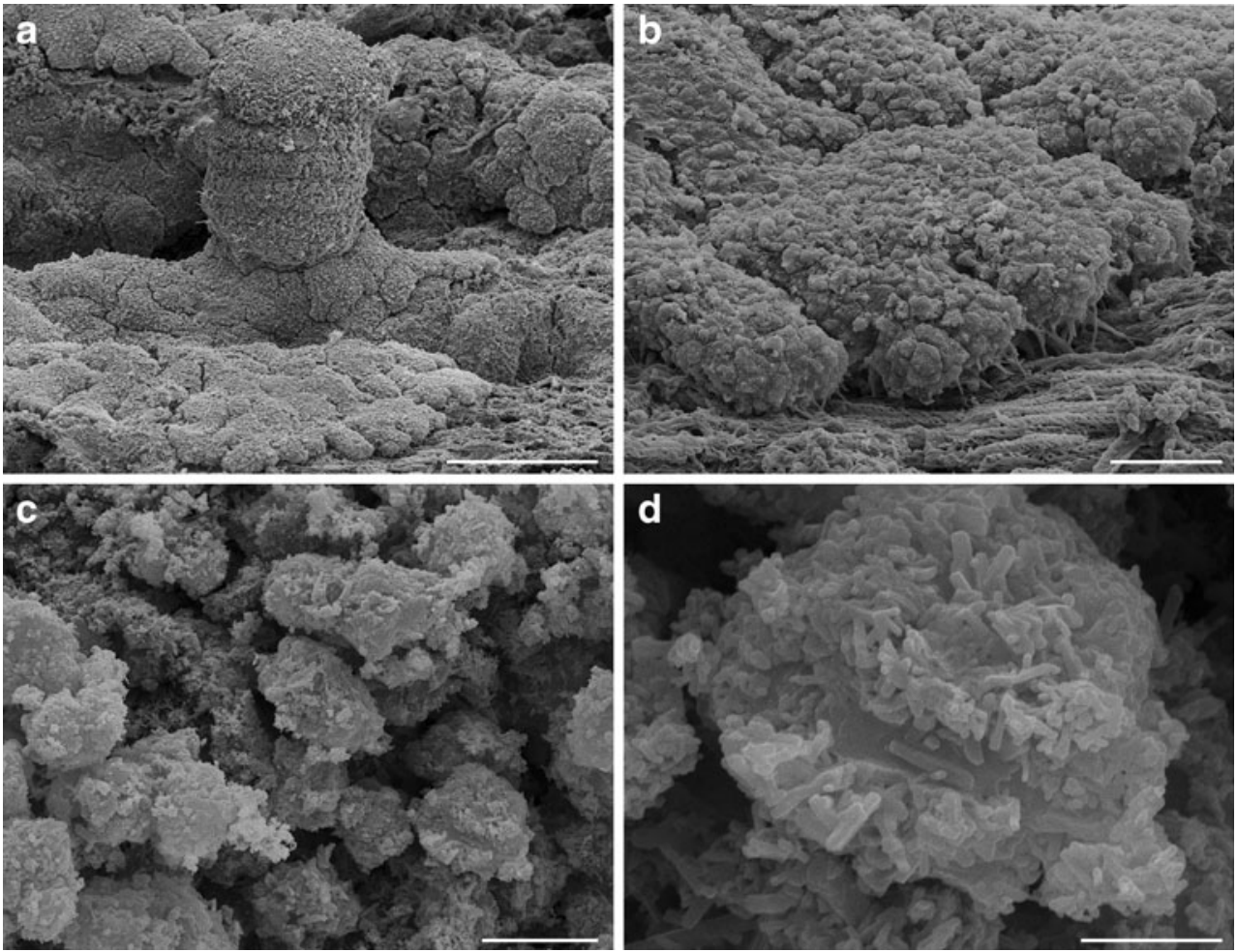

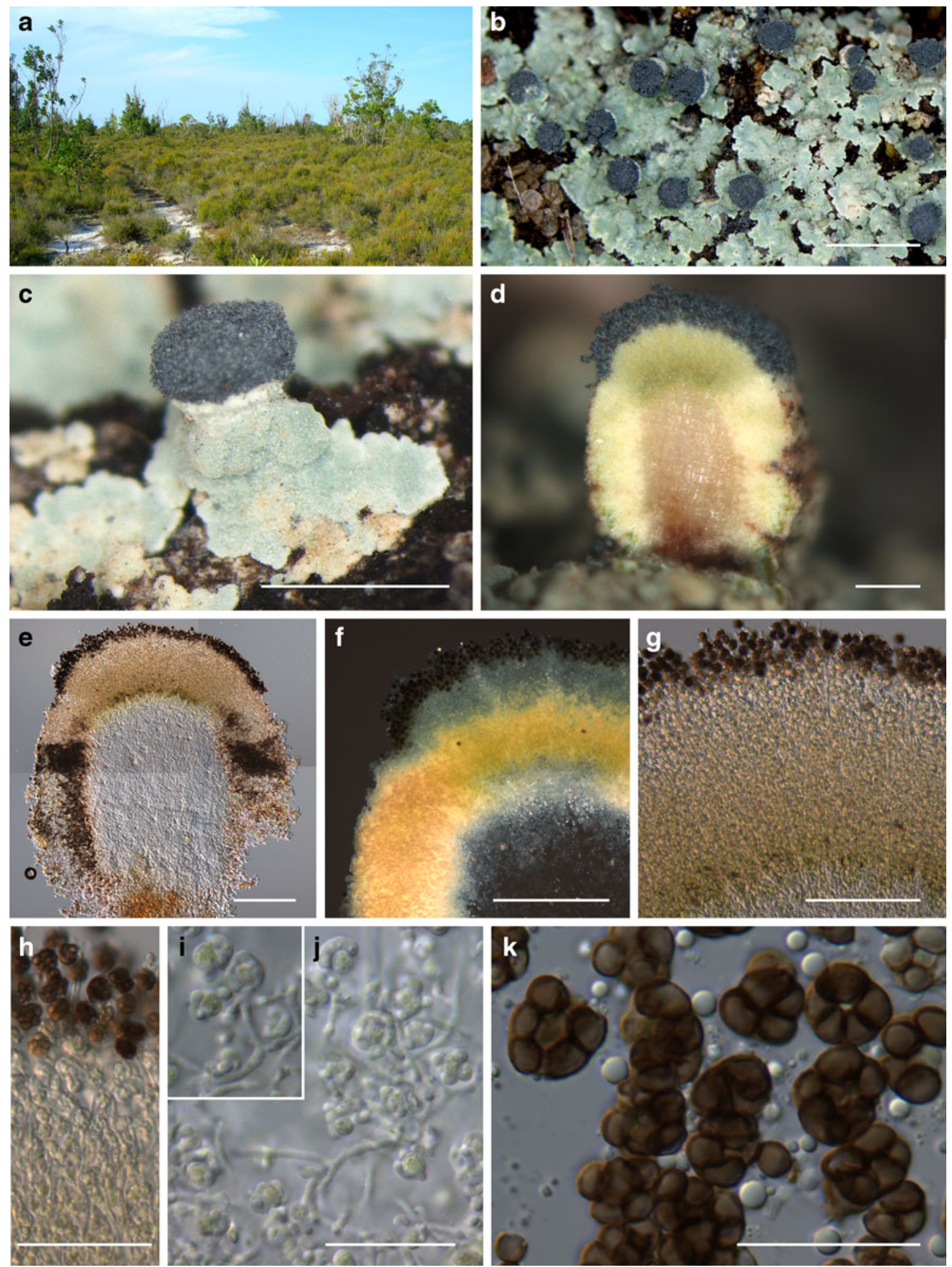

Fig. 3 Savoronala madagascariensis (b, $\mathbf{c}$ isotype LG; $\mathbf{d}-\mathbf{k}$ holotype). a Habitat, coastal heathland on dunes with Erica shrubs. b, c Thallus and sporodochia on stipes. d, e Section through a stipe and sporodochium (e in $\mathrm{KOH})$. f Section through the upper part of a stipe and sporodochium view in polarized light (in $\mathrm{H} 2 \mathrm{O}$ ). $\mathbf{g}, \mathbf{h}$ Conidiogenesis (in $\mathrm{KOH})$. $\mathbf{i}, \mathbf{j}$ Wrapping of the algae at the beginning of the conidiogenesis (in $\mathrm{KOH}$ ). k 'Mature' conidia (in $\mathrm{KOH}$ ). Scale bars (a) Erica shrubs of about $1 \mathrm{~m}$ high, (b) $2 \mathrm{~mm}$, (c) $1 \mathrm{~mm},(\mathbf{d}-\mathbf{f}) 200 \mu \mathrm{m},(\mathbf{g}) 100$ $\mu \mathrm{m}$, (h) $50 \mu \mathrm{m},(\mathbf{i}-\mathbf{k}) 20 \mu \mathrm{m}$ 
surface, sometimes slightly constricted at the base that is sometimes covered by thalline lobes, 200-700(-900) $\mu \mathrm{m}$ tall and 350-600(-800) $\mu \mathrm{m}$ thick when fully developed but sometimes almost absent; sporodochium convex, grayish blue, the same diameter or slightly wider than the stipe; upper surface uneven when covered by conidial agglomerations, when eroded becoming pale glaucous green.

Stipes in longitudinal section, when well developed, with a hyaline and loose medulla in the center surrounded by a cortex; medulla of textura intricata composed of 1- to 1.5$\mu \mathrm{m}$-thick hyphae in a gel matrix, without or with very few crystals, up to c. $480 \mu \mathrm{m}$ in diam.; algal layer present albeit poorly differentiated (only a few algal cells present between the medulla and the cortex), except under the conidiophores where the algal cells are numerous and compact; cortex c.120-200 $\mu \mathrm{m}$ thick, composed of anticlinal, \pm in parallel arranged hyaline hyphae; hyphae covered by minute crystals dissolving in $\mathrm{K}$ (best seen under polarized light); conidiophores irregularly branched, anastomosing, of 1-1.5 $\mu \mathrm{m}$ thick, forming a rather dense, hyaline, layer of c.110-190 $\mu \mathrm{m}$ thick with many hyaline conidia.

Conidia subspherical, first hyaline becoming dark brown when 'mature' at the surface of the stipes where they are easily detached to act as diaspores, covered by many tiny crystals dissolving in $\mathrm{K}$, formed by mostly $(3-) 5-8(-10)$ fungal cells, $(6-) 7-10(-12) \mu \mathrm{m}$ in diam. when brown, wrapping around a single algal cell, easily seen at early stages of the diaspores formation and before the fungal cells become brown; individual fungal cells shortly elongate, often curved and reniform, smooth, mostly $4-7 \times 2-3 \mu \mathrm{m}$ in brown conidia. Ascomata and pycnidia unknown.

Chemistry. Thallus $\mathrm{K}-, \mathrm{C}-, \mathrm{P}+$ pale yellow (weak), $\mathrm{UV}-$. Stipes and thallus in section entirely $\mathrm{I}-, \mathrm{K} / \mathrm{I}-$. TLC: zeorin and usnic acid and several unidentified UV spots after application of $10 \%$ sulfuric acid and heating (solvents B, G) (no fatty acid detected).

Distribution and ecology: Known only from the type locality in Madagascar where it was collected several times on Erica stems of a coastal Erica-grassland mosaic (Virah-Sawmy et al. 2009) on dunes composed of quartzitic sand. The open sandy places between the Erica shrubs were partly covered by large and conspicuous Cladonia cushions including C. centrophora Müll. Arg., C. cinereorubens des Abb., C. confusa (R. Sant.) Follm. \& Ahti, C. medusina (Bory) Nyl., C. praetermissa A.W. Archer, $C$. perplexa des Abb. (type locality at Fort Dauphin, which is the earlier name of Taolanaro) and C. perrieri des Abb.
The type locality belongs to the littoral forest of Madagascar which occurs on the sandy coastal plains of the eastern part of the island and represents one of the smallest and most diverse habitats (De Gouvenain and Silander 2003; Ganzhorn et al. 2001). Beside Erica, dominant shrubs include Canthium sp., Indigofera sp., Psorospermum revolutum, Ravenala madagascariensis and Vernonia nudicaulis. The locality is also famous for large populations of Nepenthes madagascariensis growing in some freshwater swamps and also on the quartzitic sand dunes. Evidence from various proxies (geochemical analyses, diatoms, pollen and charcoal) indicates that the coastal environment of eastern Madagascar has been highly dynamic over the last 6,500 years, including higher sea level (up to 1-3 m higher than present; VirahSawmy et al. 2009).

The coastal heathlands and forests are under tremendous threats (Consiglio et al. 2006) because of woodland destruction, charcoal production and the recent opening of a giant mine of ilmenite (c.6,000 ha) and the associated titane production unit by Rio Tinto Ltd. (http://www. riotintomadagascar.com).

Tylophoron Nyl. ex Stizenb.

Ber. Thät. St. Gallen Naturwiss. Ges. 1861-1862: 177 (1862). Type: Tylophoron protrudens Nyl.

Syn. nov. Sporodochiolichen Aptroot \& Sipman, Lichenologist 43: 358 (2011). Type: Sporodochiolichen lecanoricus Aptroot \& Sipman

Tylophoron hibernicum (D. Hawksw., Coppins \& P. James) Ertz, Diederich, Bungartz \& Tibell, Lichenologist 43: 354 (2011).

Basionym: Blarneya hibernica D. Hawksw., Coppins \& James, Bot. J. Linn. Soc. 79: 358 (1979).

Syn. nov. Sporodochiolichen lecanoricus Aptroot \& Sipman, Lichenologist 43: 358 (2011). Type: Papua New Guinea, Eastern Highlands Prov., Mount Gahavisuka Provincial Park, $11 \mathrm{~km} \mathrm{~N}$ of Goroka, alt. 2,300-2,450 m, on bark in mountain forest, 11 August 1992, A. Aptroot 31060 (BR-holotype!)

\section{Discussion}

Savoronala madagascariensis is easy to recognize by the following combination of characters: (1) the small, pale glaucous placodioid thalli, (2) the chlorococcoid photobiont, (3) the formation of pale cream stipes bearing grayish blue sporodochia at the apices, and (4) conidia associated and dispersed with an algal cell and dark brown when 'mature'. No other taxa throughout the lichenized fungi can be confused with Savoronala. In combination with the 
phylogenetic results, discussed in the following, we consider these differences as sufficient for the recognition of a new genus.

In our molecular analyses (Fig. 1), Savoronala was shown to be part of the family Malmideaceae where the closely related Lecidea cyrtidia, L. floridensis and L. plebeja can be included. These species share no obvious phenotypical characters with Savoronala. To our knowledge, none of these species are known to produce any kind of vegetative diaspores, nor conidia, and all have a crustose thallus (not placodioid). The three species are of uncertain generic position and need to be accommodated in other genera because the generic type [Lecidea fuscoatra (L.) Ach.] forms, with other species of Lecidea sensu stricto and Porpidia, a distinct lineage outside the Lecanorales and referred to as the Lecideales (Schmull et al. 2011).

The placement of Lecidea floridensis in the strongly supported clade with Malmidea coralliformis and M. еeunae suggest that the species might belong to the genus Malmidea. Examination of the material used by Schmull et al. (2011) of Lecidea floridensis confirmed that it belongs to the recently described genus Malmidea (Kalb et al. 2011), and more precisely to the M. piperis aggr. (Cáceres 2007; Lücking 2008). Indeed, it has a smooth or slighty rugose thallus reacting $\mathrm{UV}+$ pale yellow, apothecia biatorine, round or slightly undulating, $0.8-1.2 \mathrm{~mm}$ in diam, with a dark brown disc, a slightly prominent and pale bluish black margin, excipulum paraplectenchymatous, brown, made of radiating hyphae, slightly constricted at septa, with hydrophobic granules, paraphyses simple or more rarely branched and anastomosing, with a slightly swollen apex, clavate asci with a distinct tubular structure in the tholus, ascospores 8/ascus, simple, ellipsoid, 9-16× 5.5-6.5 $\mu \mathrm{m}$, halonate.

It is easily distinguished from Malmidea piperis (Spreng.) Kalb et al. by its whitish K- medulla (orange-red medulla $\mathrm{K}+$ purple in M. piperis). It could be a synonym of the neotropical and widespread species M. vinosa (Eschw.) Kalb et al. as we could not detect any significant morphological or anatomical difference, except for slightly smaller ascospores. We thus refrain from making the combination of Lecidea floridensis into Malmidea as the epithet may represent a mere synonym of $M$. vinosa. Both M. piperis and M. vinosa have been reported from Florida, USA (Lücking et al. 2011). As a conclusion, the specimen of Lecidea floridensis used in the phylogenetic study by Schmull et al. (2011) is a species of Malmidea Kalb et al. (2011).

Lecidea cyrtidia is saxicolous on well-lit siliceous rocks and is reported from North America (Esslinger 2011) and from Belgium and Denmark in Europe (Søchting and Alstrup 2002; Sérusiaux et al. 1999), while L. plebeja is corticolous or lignicolous, mainly on conifer stems in boreal and alpine-montane environments in North America (Esslinger 2011) and north and central Europe (Hafellner and Türk 2001; Santesson et al. 2004). These two species have an excipulum, hamathecium and ascospores very similar to those of Malmidea; they mainly differ by the absence of any lichen metabolites in the thallus (in Malmidea, the thallus can produce atranorin, norsolorinic acid, anthraquinones, biphenyls and xantholepinones; Kalb et al. 2011), excipulum outer parts comprizing cells $3-5 \mu \mathrm{m}$ wide and with dark brown apical caps, paraphyses apices slightly swollen and with brown caps, and smaller ascospores $(<10$ $\mu \mathrm{m} \times 2.5-4 \mu \mathrm{m})($ Coppins and Muhr 1997; Sérusiaux et al. 1999). They most probably represent an undescribed genus within the Malmideaceae.

We decided to name as 'conidia' the vegetative propagules produced at the stipes of Savoronala despite the fact that one algal cell is wrapped and completely surrounded by the fungus hyphae, and is thus dispersed altogether with the fungal 'conidia'. A process of conidiogenesis is indeed visible and the cells of mature conidia strongly differ from those of the 'carrying hyphae' (=conidiophores), becoming slightly larger and dark brown. The conidiogenesis can be compared with that of the aeroaquatic hyphomycete Spirosphaera Beverw. (Marvanová and Bärlocher 1998); the conidia arise apically or laterally on undifferenciated conidiophores, and are rapidly septate and inflating, and further coiling up. In Savoronala, a single algal cell, out of those present within the conidiophores-producing tissue, is wrapped up by the coiling conidia; the conidia cells further become larger and brown.

Dispersal of conidia together with algal cell is a rare phenomenon in lichenized fungi, being so far restricted to highly specialized conidiomata structures. Indeed, only the hyphophores within the subfamily Gomphilloideae (Rivas Plata et al. 2012) and the campylidia within the Pilocarpaceae (Sérusiaux 1986; Lücking 2008; Vězda 1986) can disperse their conidia and algal cells all together. In the Gomphilloideae, several genera produce conidia or conidia-like "diahyphae" in specialized conidiomata, here named hyphophores, that are dispersed with algal cells, usually mixed up within the conidial mass, but not genuinely wrapped up by conidia. The following genera are concerned: Actinoplaca Müll. Arg., Calenia Müll. Arg., Gyalectidium Müll. Arg. and Jamesiella Lücking, Sérus. \& Vězda (Lücking et al. 2005).

Within the Pilocarpaceae s.l., several genera produce campylidia in which algal cells occur within the conidiogenous layer. In those genera, algal cells are expelled 
with conidia, sometimes in a sticky mass that can be seen at the opening of the campylidium (Sérusiaux 1986). The following genera are concerned: Sporopodium Mont., Tapellaria Müll. Arg. and Tapellariopsis Lücking (Sanders and Lücking 2002; Lücking 2008). In the genus Sporopodiopsis Sérus. (Sérusiaux 1997), the campylidia are organized in such a way that, although algal cells are not present within the campylidia cavity, conidia can "collect" algal cells on their way out and disperse with them.

Malme (1935) could observe conidia being wrapped up by filiform conidia in Calopadia perpallida (Nyl.) Vězda, but recent studies (Lücking 2008) could not confirm this observation; we suspect that Malme was observing the campylidia of a species of Tapellaria or Sporopodium. Sanders and Lücking (2002) featured filiform conidia encircling algal cells at a very early stage of the thallus growth in Tapellariopsis octomera; association between conidia and algal cells in this species could merely be the result of the conidia being strongly curved (Lücking 1999). With the data available, formation and dispersal of conidia wrapping up tightly algal cells (here always a single one) have never been documented for lichenized fungi.

We also addressed the question that the stipes of Savoronala might represent highly modified campylidia, but we did not find any obvious character to support this hypothesis. The diaspores of Savoronala, being a firmly attached assemblage of the photo- and mycobionts, are also reminiscent of 'goniocyst', a term that has been used for different types of diaspores containing algae (see Sérusiaux et al. 2006 for detailed discussion about the origin and use of the term 'goniocyst'). However, it is usually applied for tiny thallus granules, always without any process of conidiogenesis. As examples, the thallus of most Malmidea species is composed of goniocysts (Kalb et al. 2011) and Nyungwea Sérus., Eb. Fisch. \& Killmann produces goniocysts on erected stipes, but here the stipes are made entirely of loose hyphae and the photobiont belongs to Trentepohlia (Sérusiaux et al. 2006). The diaspores of Gallaicolichen Sérus. \& Lücking (Sérusiaux and Lücking 2007) represent a very different morphological pattern, as here the photobiont (belonging to the genus Phycopeltis) is the wrapping up agency as it does envelop its mycobiont partner; those diaspores are named peltidia.

The lichenized hyphomycete Dictyocatenulata alba Finley \& E.F. Morris (Aptroot and Schiefelbein 2003; Diederich et al. 2008; Lendemer and Harris 2004) also produces subspherical, muriform conidia at the apices of stipes; however, the species differs strongly from
Savoronala by a very thin, crustose thallus with trentepohlioid algae, synnematal conidiomata and hyaline conidia not associated with any algal cell. Cheiromycina B. Sutton is a small lichen-forming hyphomycete genus of uncertain affiliation that produces sporodochia and has a chlorococcoid photobiont (Aptroot and Schiefelbein 2003; Hawksworth and Poelt 1990; Printzen 2007; Sutton and Muhr 1986); it differs from Savoronala by sessile sporodochia with hyaline, rarely pale brown at the base, palmately branched conidia not associated to any algae and subspherical to shortly ellipsoid conidiogenous cells (with C. globosa Aptroot \& Schiefelbein being atypical for the genus by having unicellular, globose to slightly ellipsoid conidia, whereas conidiogenous cells were not recognized by the authors).

Several other lichenized taxa are known to produce sporodochia (Table 2). Among the Lecanorales, Byssoloma gahavisukanum Sérus. differs by its epiphyllous and very thin thallus forming sessile bluish sporodochia with vertical chains of up to 20, ellipsoid to slightly lacrimiform conidia (Aptroot et al. 1997); Micarea adnata Coppins differs by a pale gray-green, \pm waxy thallus producing simple, cylindrical to oblong ellipsoid macroconidia in non-stipitate, whitish sporodochia (Coppins 1983); the monotypic genus Xyleborus R. C. Harris \& Ladd [type species X. sporodochifer (Harris and Ladd 2007)], placed in the Stereocaulaceae, differs by a pale to olivaceous thallus producing globose, hyaline conidia in white, hemisphaerical to subglobose, sessile sporodochia. All these taxa are also known to produce apothecia. Several lichenized taxa producing sporodochia are also known among the Arthoniales, but all have trentepohlioid photobionts; e.g., Milospium (Aptroot and Sipman 2001), Reichlingia (Diederich and Coppins 2009), 'Sclerococcum' griseisporodochium Etayo (Etayo 1995; the generic affiliation of this Arthoniales needs further study since the generic type of Sclerococcum, S. sphaerale, was resolved in the Eurotiomycetes by Diederich et al. 2012), Tylophoron (Ertz et al. 2011; Tibell 1991). Sporodochiolichen Aptroot \& Sipman includes four species (Aptroot and Sipman 2011), but the generic type (S. lecanoricus Aptroot \& Sipman) is obviously conspecific with Tylophoron hibernicum (D. Hawksw., Coppins \& P. James) Ertz, Diederich, Bungartz \& Tibell, despite the photobiont was said to be myrmecioid. As a consequence, the genus Sporodochiolichen is here reduced into synonymy with Tylophoron (see "Results"). The three other species of Sporodochiolichen differ from Savoronala by golden yellow or pink, sessile sporodochia and generally simple or 1-distoseptate conidia; their phylogenetic position remains to be determined. 


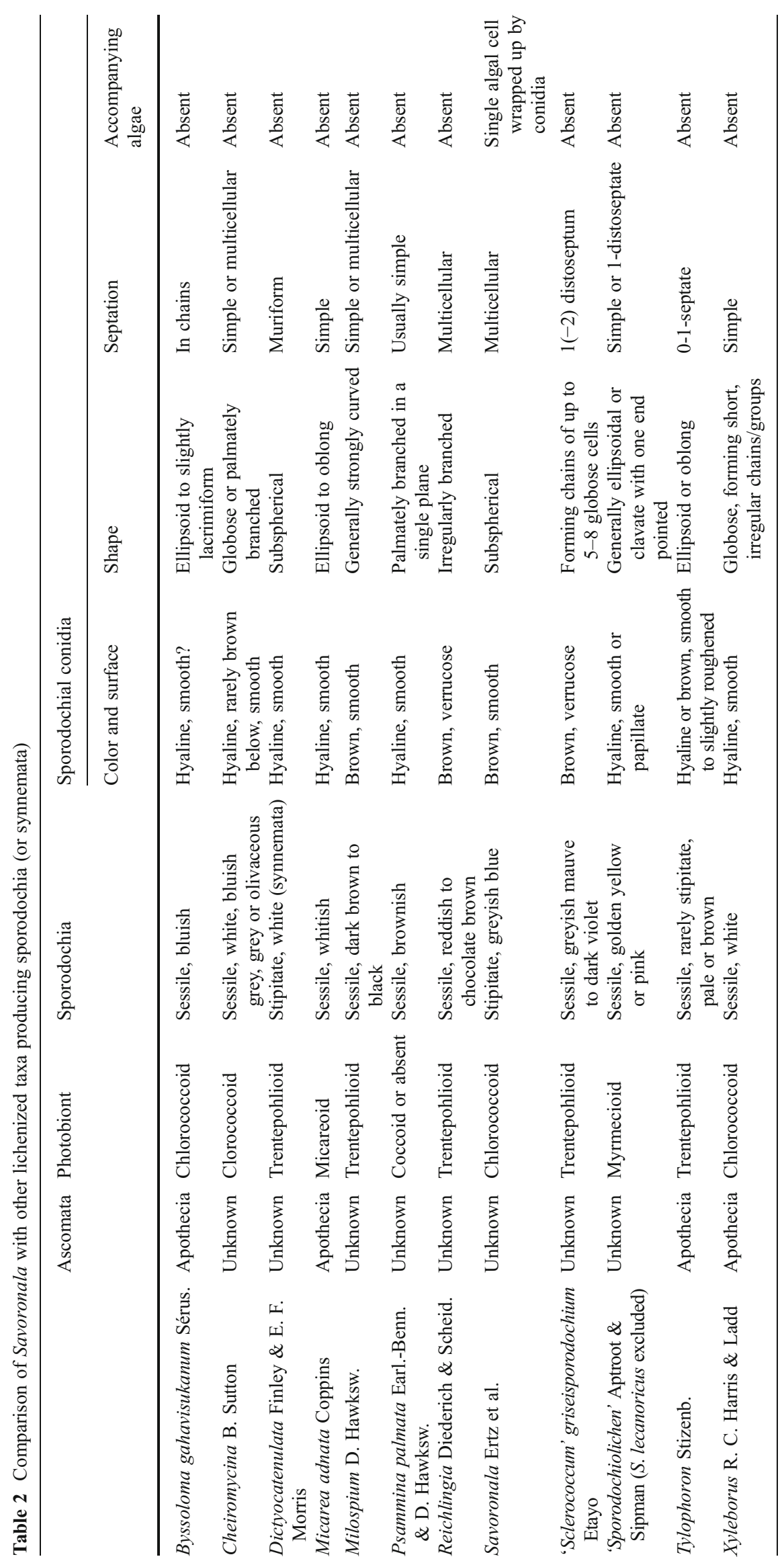


Acknowledgements We are indebted to the staff of the Parc Botanique et Zoologique de Tsimbazaza in Antananarivo for logistical support of our research. We would like to thank the Ministère des Eaux et Forêts for collection and export permits of scientific material and Michaela Schmull (FH) for the loan of the specimens Lecidea floridensis (May 3088) and Lecidea plebeja (L. 'sp. 1', Motiejunaite 7695). Cyrille Gerstmans, Francine Demuylder, Laurent Gohy, Ido Cremasco and Hans-Jürgen Ensikat are thanked for technical assistance. We are grateful to the Director of the Nees Institute for Biodiversity of Plants, Prof. Dr. Wilhelm Barthlott, for the permission to use the scanning electron microscope. We would also like to thank two anonymous referees for providing us with constructive comments and suggestions. Finally, the authors acknowledge financial support from the Fonds National de la Recherche Scientifique (FNRS) from Belgium (F.R.F.C. \# 2.4515.06) and from the Academy of Sciences and Literature Mainz.

\section{References}

Aptroot A (2012) Checklist of lichens and lichenicolous fungi of Madagascar. Available at http://www.biologie.uni-hamburg.de/ checklists/lichens/africa/madagascar_l.htm. Accessed 9 July 2012

Aptroot A, Schiefelbein U (2003) Additional species of Cheiromycina (lichenized hyphomycetes), with a key to the known species. Mycol Res 107:104-107

Aptroot A, Sipman HJM (2001) New Hong Kong lichens, ascomycetes and lichenicolous fungi. J Hattori Bot Lab 91:317-343

Aptroot A, Sipman HJM (2011) Sporodochiolichen, a new genus of tropical hyphomycetous lichens. Lichenologist 43:357-362

Aptroot A, Diederich P, Sérusiaux E, Sipman H (1997) Lichens and lichenicolous fungi from New Guinea. Biblioth Lichenol 64:1-220

Cáceres M (2007) Corticolous crustose and microfoliose lichens of northeastern Brazil. Libri Botanici 22:1-168

Consiglio T, Schatz GE, McPherson G, Lowry PP II, Rabenantoandro J, Rogers ZS, Rabevohitra R, Rabehevitra D (2006) Deforestation and plan diversity of Madagascar's littoral forests. Conserv Biol 20:1799-1803

Coppins BJ (1983) A taxonomic study of the lichen genus Micarea in Europe. Bull Brit Mus (Nat Hist) Bot 11:17-214

Coppins BJ, Muhr L-E (1997) Micarea lapillicola (Vain.) Coppins \& Muhr, a previously misunderstood species from NW Europe. Graphis Scr 8:45-49

Cubero OF, Crespo A, Fathi J, Bridge PD (1999) DNA extraction and PCR amplification method suitable for fresh, herbarium-stored, lichenized, and other fungi. Plant Syst Evol 216:243-249

Cunningham CW, Zhu H, Hillis DM (1998) Best-fit maximum likelihood models for phylogenetic inference: empirical tests with known phylogenies. Evolution 52:978-987

De Gouvenain RC, Silander AA (2003) Littoral forest. In: Goodman SM, Benstead JP (eds) The natural history of Madagascar. University of Chicago Press, Chicago, pp 103-111

Diederich P, Coppins BJ (2009) Reichlingia Diederich \& Scheid. In: Smith CW, Aptroot A, Coppins BJ et al (eds) The lichens of Great Britain and Ireland. British Lichen Society, London, pp 790-791

Diederich P, Palice Z, Ertz D (2008) Cheiromycina ananas is a synonym of Dictyocatenulata alba, a widespread, lichenized, synnematous hyphomycete herewith reported as new for Europe. Sauteria 15:205-214

Diederich P, Ertz D, Lawrey JD, Sikaroodi M, Untereiner WA (2012) Molecular data place the hyphomycetous lichenicolous genus Sclerococcum close to Dactylospora (Eurotiomycetes) and $S$. parmeliae in Cladophialophora (Chaethothyriales). Fungal Diversity. doi:10.1007/s13225-012-0179-4
Ertz D, Killmann D, Razafindrahaja T, Sérusiaux E, Fischer E (2010) Two new species of Syncesia (Arthoniales, Roccellaceae) from Africa. Lichenologist 42:43-49

Ertz D, Bungartz F, Diederich P, Tibell L (2011) Molecular and morphological data place Blarneya in Tylophoron (Arthoniaceae). Lichenologist 43:345-356

Esslinger TL (2011) A cumulative checklist for the lichen-forming, lichenicolous and allied fungi of the continental United States and Canada. North Dakota State University: http://www.ndsu.edu/ pubweb/ esslinge/chcklst/chcklst7.htm (First Posted 1 December 1997, Most Recent Version (\#17) 16 May 2011), Fargo, North Dakota

Etayo J (1995) Two new species of lichenicolous fungi from the Pyrenees. Nova Hedwigia 61:189-197

Ganzhorn JU, Lowry PP, Schatz GE, Sommer S (2001) The biodiversity of Madagascar: one of the world's hottest hotspot on its way out. Oryx 35:346-348

Glaw F, Köhler J, Townsend TM, Vences M (2012) Rivaling the world's smallest reptiles: Discovery of miniaturized and microendemic new species of leaf chameleons (Brookesia) from northern Madagascar. PLoS ONE 7(2), doi:10.1371/journal. pone. 0031314

Goodman SM, Beanstead JP (eds) (2003) The Natural History of Madagascar. University of Chicago Press, Chicago

Hafellner J, Türk R (2001) Die lichenisierten Pilze Österreichs - eine Checkliste der bisher nachgewiesenen Arten mit verbreitungsangaben. Stapfia 76:1-167

Harris RC, Ladd D (2007) New taxa of lichens and lichenicolous fungi from the Ozark Ecoregion. Opusc Philolichenum 4:57-68

Hawksworth DL, Poelt J (1990) A second lichen-forming species of Cheiromycina from Austria. Lichenologist 22:219-224

Huelsenbeck JP, Ronquist F (2001) MRBAYES: Bayesian inference of phylogeny. Bioinformatics 17:754-755

Kalb K, Rivas Plata E, Lücking R, Lumbsch HT (2011) The phylogenetic position of Malmidea, a new genus for the Lecidea piperisand Lecanora granifera-groups (Lecanorales, Malmideaceae) inferred from nuclear and mitochondrial ribosomal DNA sequences, with special reference to Thai species. Biblioth Lichenol 106:143-168

Kauff F, Lutzoni F (2002) Phylogeny of the Gyalectales and Ostropales (Ascomycota, Fungi): among and within order relationships based on nuclear ribosomal RNA small and large subunits. Mol Phylogenet Evol 25:138-156

Lendemer JC, Harris RC (2004) A checklist of the lichens collected on the 28th A Leroy Andrews Foray. Evansia 21:88-100

Liò P, Goldman N (1998) Models of molecular evolution and phylogeny. Genome Res 8:1233-1244

Lücking R (1999) Ergänzungen und Verbesserungen zur Kenntnis der foliikolen Flechtenflora Costa Ricas. Die Familie Ectolechiaceae. Phyton 39:131-165

Lücking R (2008) Foliicolous Lichenized Fungi. Flora Neotropica Monograph 103, Organization for Flora Neotropica and The New York Botanical Garden Press, New York

Lücking R, Sérusiaux E, Vězda A (2005) Phylogeny and systematics of the lichen family Gomphillaceae (Ostropales) inferred from cladistics analyses of phenotype data. Lichenologist 37:123-170

Lücking R, Seavey F, Common RS, Beeching SQ, Breuss O, Buck WR, Crane L, Hodges M, Hodkinson BP, Lay E, Lendemer JC, McMullin RT, Mercado-Díaz JA, Nelsen MP, Rivas Plata E, Safranek W, Sanders WB, Schaefer HP, Seavey J (2011) The lichens of Fakahatchee Strand Preserve State Park, Florida: Proceedings from the 18th Tuckerman Workshop. Bull Florida Mus Nat Hist 49:127-186

Maddison D \& Maddison W (2002) MacClade version 4.03PPC: Analysis of phylogeny and character evolution. Sinauer, Sunderland, Massachusetts, USA.11. 
Malme GO (1935) Das Kampylidium, ein verkanntes Fortpflanzungsorgan der Flechten. Svensk Bot Tidskr 29:302-305

Marvanová L, Bärlocher F (1998) Hyphomycetes from Canadian streams. IV. Spirosphaera dimorpha sp. nov. Mycotaxon 68:33-40

Mason-Gamer RJ, Kellogg EA (1996) Testing for phylogenetic conflict among molecular datasets in the tribe Triticeae (Gramineae). Syst Biol 45:524-545

Miller MA, Pfeiffer W, Schwartz T (2010) Creating the CIPRES Science Gateway for inference of large phylogenetic trees. In: Proceedings of the Gateway Computing Environments Workshop (GCE), 14 Nov. 2010, New Orleans, LA, pp 1-8.

Myers N, Mittermeier RA, Mittermeier CG, da Fonseca GAB, Kent J (2000) Biodiversity hotspots for conservation priorities. Nature 403:853-858

Orange A, James PW, White FJ (2001) Microchemical methods for the identification of lichens. British Lichen Society, London

Posada D, Crandall KA (1998) MODELTEST: Testing the model of DNA substitution. Bioinformatics 14:817-818

Printzen C (2007) New records of Cheiromycina species, a genus of lichenized hyphomycetes, with $C$. reimeri sp. nov. and a revised key to the species. Nova Hedwigia 84:261-267

Radespiel U, Ratsimbazafy JH, Rasoloharijaona S, Raveloson H, Andriaholinirana N, Rakotondravony R, Randrianarison RM, Randranabinina B (2012) First indications of a highland specialist among mouse lemurs (Microcebus spp.) and evidence for a new mouse lemur species from eastern Madagascar. Primates 53:157-170

Rambaut A (2012) FigTree v1.3.1, available from: http://tree.bio.ed. ac.uk/software/figtree/

Rambaut A, Drummond AJ (2007) Tracer v1.5., available from: http:// beast.bio.ed.ac.uk/Tracer

Rehner SA, Samuels GJ (1994) Taxonomy and phylogeny of Gliocladium analyzed by large subunit rDNA sequences. Mycol Res 98:625-634

Rivas Plata E, Lücking R, Lumbsch HT (2012) A new classification for the family Graphidaceae (Ascomycota: Lecanoromycetes: Ostropales). Fungal Divers 52:107-121

Ronquist F, Huelsenbeck JP (2003) MRBAYES 3: Bayesian phylogenetic inference under mixed models. Bioinformatics 19:1572-1574

Sanders WB, Lücking R (2002) Reproductive strategies, relichenization and thallus development observed in situ in leaf-dwelling lichen communities. New Phytol 155:425-435

Santesson R, Moberg R, Nordin A, Tønsberg T, Vitikainen O (2004) Lichen-forming and Lichenicolous Fungi of Fennoscandia. Museum of Evolution. Uppsala University, Uppsala

Schatz GE, Lowry PP II, Lescot M, Wolf A-E, Andriambololonera S, Raharimalala V, Raharimampionona J (1996) Conspectus of the vascular plants of Madagascar: a taxonomic and conservation electronic database. In: van der Maesen LJG, van der Burgt XM, van Medenbach de Rooy JM (eds) The Biodiversity of African Plants. Kluwer, Wageningen, The Netherlands, pp 10-17
Schmull M, Miadlikowska J, Pelzer M, Stocker-Wörgötter E, Hofstetter V, Fraker E, Hodkinson BP, Reeb V, Kukwa M, Lumbsch HT, Kauff F, Lutzoni F (2011) Phylogenetic affiliations of members of the heterogeneous lichen-forming fungi of the genus Lecidea sensu Zahlbruckner (Lecanoromycetes, Ascomycota). Mycologia 103:983-1003

Schoch CL, Sung GH, López-Giráldez F, Townsend JP, Miadlikowska J, Hofstetter J et al (2009) The ascomycota tree of life: A phylumwide phylogeny clarifies the origin and evolution of fundamental reproductive and ecological traits. Syst Biol 58:224-239

Sérusiaux E (1986) The nature and origin of campylidia in lichenized fungi. Lichenologist 18:1-35

Sérusiaux E (1997) Sporopodiopsis, a new genus of lichens (Ectolechiaceae) from S-E Asia. Abstr Bo 21:145-152

Sérusiaux E, Lücking R (2007) Gallaicolichen, a new genus of foliicolous lichen with unique diaspores. Biblioth Lichenol 95:509-516

Sérusiaux E, Diederich P, Brand AM, van den Boom P (1999) New or interesting lichens and lichenicolous fungi from Belgium and Luxembourg. VIII. Lejeunia 162:1-95

Sérusiaux E, Fischer E, Killmann D (2006) Nyungwea, a new genus of lichen with goniocyst-producing stipes from Rwanda and Uganda (East Africa). Lichenologist 38:115-121

Søchting U, Alstrup U (2002) Danish lichen checklist. Botanical Institute, University of Copenhagen, Copenhagen

Sutton BC, Muhr LE (1986) Cheiromycina flabelliformis gen. et sp. nov. on Picea from Sweden. Nord J Bot 6:831-836

Swofford DL (2002) PAUP*: phylogenetic analysis using parsimony (*and other methods). Version 4. Sinauer, Sunderland

Tibell L (1991) The anamorph of Tylophoron moderatum. Mycol Res 95:290-294

van den Boom P, Ertz D, Brand M, Sérusiaux E (2011) Syncesia mascarena (Roccellaceae) a new species from La Réunion (Indian Ocean). Opusc Philolichenum 9:5-10

Vězda A (1986) Neue Gattungen der Familie Lecideaceae s. lat. (Lichenes). Folia Geobot Phytotax 21:199-219

Vilgalys R, Hester M (1990) Rapid genetic identification and mapping of enzymatically amplified ribosomal DNA from several Cryptococcus species. J Bacteriol 172:4238-4246

Virah-Sawmy M, Willis KJ, Gillson L (2009) Threshold response of Madagascar's littoral forest to sea-level rise. Glob Ecol Biogeogr 18:98-110

Yang Z, Goldman N, Friday A (1994) Comparison of models for nucleotide substitution used in maximum-likelihood phylogenetic estimation. Mol Biol Evol 11:316-324

Zoller S, Scheidegger C, Sperisen C (1999) PCR primers for the amplification of mitochondrial small subunit ribosomal DNA of lichen-forming ascomycetes. Lichenologist 31:511-516

Zwickl DJ (2006) Genetic algorithm approaches for the phylogenetic analysis of large biological sequence datasets under the maximum likelihood criterion. $\mathrm{PhD}$ dissertation, The University of Texas at Austin 